\title{
Seed Yield and Nutrient Content of Mungbean and Soil Nutrient Status as Influenced by Application of Micronutrients Mixture in a Alfisol
}

\author{
K.S. Divyashree*, S.S. Prakash, S.B. Yogananda and Chandrappa \\ University of Agricultural Sciences, Bengaluru, Karnataka, India \\ *Corresponding author
}

\begin{tabular}{|c|}
\hline Keywords \\
\hline $\begin{array}{l}\text { Mungbean, } \\
\text { Micronutrients mixture } \\
\text { (MM), Soil application, } \\
\text { Foliar application, Seed } \\
\text { treatment, Nutrient } \\
\text { content }\end{array}$ \\
\hline Article Info \\
\hline $\begin{array}{l}\text { Accepted: } \\
12 \text { August } 2018 \\
\text { Available Online: } \\
\text { 10 September } 2018\end{array}$ \\
\hline
\end{tabular}

\section{Introduction}

India is recognised as the principal producer, consumer, processor and importer of pulses in the world. Paradoxically, the country pulse production has reached at 19.5 million tonnes from the acreage of 24.5 million hectares. Expectedly, as the countries domestic requirements would be around $26.50 \mathrm{mt}$ by 2030, it necessitates stepping up of production by almost $7.0 \mathrm{mt}$ of additional produce. Pulses are rich source of protein and they maintain
The lower productivity of pulses in India is largely due to cultivation of pulses on marginal and sub-marginal lands as main crop or after the harvest of main cereal crop with less or no fertilizer application. Such cultivation practices not only results in lowering of soil fertility and productivity also results in grains low in mineral nutrient elements, consumption of such grains may cause serious health issue in human beings. Keeping these points in view the experiment was laid out in RCBD with twelve treatments including control, RDF alone, RDF + water spray / soil / foliar (Fe, Mn, Zn, Cu and B) application, RDF + seed treatment with MM + Mo and RDF + soil application of deficient micronutrients ( $\mathrm{Zn}$ and $\mathrm{B}$ ). Results revealed that application of RDF + foliar application of at 30 and 45 DAS recorded significantly higher nutrient content of $\mathrm{Fe}, \mathrm{Mn}, \mathrm{Zn}, \mathrm{Cu}$ B in mungbean seeds, which was $77.44,80.9,65.77,30.68$ and 65.39 per cent, respectively higher over control and 43.99, 66.2, 17.90, 21.16 and 20.94 percent, respectively higher over soil application of MM. The soil DTPA extractable iron, zinc and boron content was highest in the treatment receiving soil application of micronutrients mixture along with RDF. The increased availability of micronutrients in the soil significantly improved the nutrient content and grain yield $\left(1140.84 \mathrm{~kg} \mathrm{ha}^{-1}\right)$ of mungbean with the foliar and soil application of micronutrients. 
Supplies of nutrients are more important in pulses because early flowering altered the source-sink relationship due to rapid translocation of nutrients from leaves to the developing pods. The diets of over two-thirds of the world's population lack in one or more essential mineral elements. This can be remedied through increasing the concentrations and/or bioavailability of mineral elements in produce. To overcome these constraints, nutrition through foliar feeding play a vital role in pulse production by stimulating root development, nodulation, energy transformation, various metabolic processes and increasing pod setting and thereby increasing the yield and also increasing the soil fertility through application besides increasing the content in grains. Foliar spray is one of the most efficient ways of supplying essential nutrients to a growing crop.

\section{Materials and Methods}

The field experiment was conducted at College of Agriculture, V.C. Farm, Mandya situated in the Agro Climatic Zone-6, Southern Dry Zone, Karnataka. It lies between $76^{\circ} 49^{\prime} 08^{\prime \prime}$ E longitude and $12^{\circ} 34^{\prime} 03^{\prime \prime} \mathrm{N}$ latitude with 697 meters above mean sea level. The twelve treatments combinations including $\mathrm{T}_{1}$ : Absolute control, $\mathrm{T}_{2}$ : Only RDF, $\mathrm{T}_{3}$ : $\mathrm{T}_{2}+$ water spray, $\mathrm{T}_{4}$ : $\mathrm{T}_{2}+$ foliar application of $\mathrm{MM}$ at $30 \mathrm{DAS}, \mathrm{T}_{5}: \mathrm{T}_{2}+$ foliar application of $\mathrm{MM}$ at 45 DAS, $\mathrm{T}_{6}: \mathrm{T}_{2}+$ foliar application of $\mathrm{MM}$ at $30 \& 45 \mathrm{DAS}, \mathrm{T}_{7}: \mathrm{T}_{2}+$ foliar application of deficient $\mathrm{MM}$ at $30 \mathrm{DAS}, \mathrm{T}_{8}$ : $\mathrm{T}_{2}+$ Mo seed treatment + foliar application of deficient $\mathrm{MM}$ at 30 DAS, $\mathrm{T}_{9}: \mathrm{T}_{2}+$ soil application of $\mathrm{MM}$, $\mathrm{T}_{10}: \mathrm{T}_{2}$ +soil application of deficient MM, $\mathrm{T}_{11}$ : $\mathrm{T}_{2}+\mathrm{Mo}$ seed treatment + soil application of deficient MM, $\mathrm{T}_{12}: \mathrm{T}_{2}+$ Mo seed treatment + MM seed treatment. All twelve treatments combinations were replicated three times in Randomized block design.

The soil was sandy loam in texture with 75.03 ,
18.2, and 6.77 per cent sand, silt and clay, respectively and bulk density of $1.5 \mathrm{Mg} \mathrm{m}^{-3}$. The soil was neutral in reaction $(\mathrm{pH} \mathrm{7.21)}$ and low in soluble salts $\left(0.16 \mathrm{dS} \mathrm{m}^{-1}\right)$. The soil was low in organic carbon $\left(4.8 \mathrm{~g} \mathrm{~kg}^{-1}\right)$, available nitrogen $\left(151.2 \mathrm{~kg} \mathrm{ha}^{-1}\right)$ and available $\mathrm{P}_{2} \mathrm{O}_{5}\left(9.64 \mathrm{~kg} \mathrm{ha}^{-1}\right)$, while it was medium in $\mathrm{K}_{2} \mathrm{O}\left(202.944 \mathrm{~kg} \mathrm{ha}^{-1}\right)$ and high in sulphur (15.67 mg kg-1). The exchangeable calcium and magnesium content of soil was 3.4 and $2.5 \mathrm{meq} 100 \mathrm{~g}^{-1}$, respectively. The DTPA extractable micronutrient content viz., zinc, iron, copper manganese and boron were $0.52,7.82,0.41,8.62$ and $0.46 \mathrm{mg} \mathrm{kg}^{-1}$, respectively. $\mathrm{Zn}$ and $\mathrm{B}$ content were below the critical limit. Mungbean variety KKM-3 was sown at $30 \mathrm{~cm}$ row and $10 \mathrm{~cm}$ plant to plant apart. Recommended dose of $\mathrm{N}, \mathrm{P}_{2} \mathrm{O}_{5}$ and $\mathrm{K}_{2} \mathrm{O}$ for greengram is $20: 50: 50 \mathrm{~kg} \mathrm{ha}^{-1}$ was supplied with urea, single super phosphate and murate of potash respectively and micronutries like $\mathrm{Fe}, \mathrm{Mn}, \mathrm{Zn}, \mathrm{Cu}, \mathrm{B}$ and Mo was applied in the form of iron sulphate, manganese sulphate, zinc sulphate, copper sulphate, borax and ammonium molybdate, respectively. To reduce weed infestation one hand weeding was done at 25 days after sowing. In all 4 irrigations were given at different stages of crop growth to fulfill the water requirement. To control the whitefly (Bemisia tobaci), Roger 30 EC @ 1.0 litre ha ${ }^{-1}$ was uniformly sprayed at vegetative growth stage of the crop. Crop was harvested at physiological maturity. Observations were recorded at harvest in order to assess the effect of micronutrients mixture on seed yield and nutrient content. The nutrient content in mungbean was assessed after digestion by following standard protocol. Micronutrient cations ( $\mathrm{Fe}, \mathrm{Mn}, \mathrm{Zn}$ and $\mathrm{Cu}$ ) from soil were extracted with DTPA extractant $(0.005 \mathrm{M}$ Diethylene Triamine Penta Acetic acid + $0.01 \mathrm{M} \mathrm{CaCl}_{2}+0.1 \mathrm{M}$ Triethanolamine) buffered to $\mathrm{pH} 7.3$ at 1:2 soil to extractant ratio as described by Lindsay and Norvell (1978). The concentration of these cations was determined by atomic absorption 
spectrophotometer under suitable measuring conditions (Page et al., 1982).

\section{Micronutrients mixture composition}

Among the micronutrients, $\mathrm{Zn}$ and $\mathrm{B}$ were found to be deficient in the experimental soil. Besides these two nutrients other micronutrients ( $\mathrm{Fe}, \mathrm{Mn}, \mathrm{Cu}, \mathrm{Mo}$ ) were also used in the micronutrients mixture preparation. The proportion of salts used along with per cent nutrient content is presented in Table 1.

\section{Results and Discussion}

Effect of micronutrient mixture on yield of crop

Significantly superior yield of $1140.84 \mathrm{~kg} \mathrm{ha}^{-1}$ was registered in RDF + foliar application of micronutrients mixture at 30 and 45 DAS followed by $1064.56 \mathrm{~kg} \mathrm{ha}^{-1}$ with the application of $\mathrm{RDF}+$ soil application of micronutrients mixture (Fig. 1). Suggesting the foliage supplementation of micronutrients as basal enhances the early vigour and thus helps in better growth and yield parameters. Similarly, foliar application at later stages is responsible for translocation of assimilates to sink thus resulting in higher nutrient content in grains. It may be attributed to the enhanced growth as a result of supply of micronutrients two times. Significantly higher stover yield of $2483.86 \mathrm{~kg} \mathrm{ha}^{-1}$ was recorded due to soil application of RDF+MM followed by 2386.63 and $2333.13 \mathrm{~kg} \mathrm{ha}^{-1}$ due to $\mathrm{T}_{10}(\mathrm{RDF}+$ soil application of deficient micronutrients) and $\mathrm{T}_{6}$ (RDF + foliar application of MM at 30 and 45 DAS) respectively compared to control $\left(1831.97 \mathrm{~kg} \mathrm{ha}^{-1}\right)$. The higher yield obtained with application of micronutrients along with RDF might be due to increased availability of nutrients in balanced proportion. Similar increase in the productivity of pulses with the foliar spray of $\mathrm{Zn}, \mathrm{Fe}, \mathrm{B}, \mathrm{Mn}$ and Mo was reported by Savithri (2001).

\section{Effect of micronutrients mixture on nutrient content in mungbean}

Application of micronutrients mixture significantly influenced the micronutrient content of mungbean grain. Iron content in control was $84.10 \mathrm{mg} \mathrm{kg}^{-1}$ which increased significantly to $149.23 \mathrm{mg} \mathrm{kg}^{-1}$ due to application of RDF + foliar spray of MM at 30 and 45 DAS $\left(T_{6}\right)$. The highest concentration of iron in stover was recorded in $\mathrm{T}_{6}(720.39 \mathrm{mg}$ $\left.\mathrm{kg}^{-1}\right)$, followed by $\mathrm{T}_{4}\left(696.90 \mathrm{mg} \mathrm{kg} \mathrm{kg}^{-1}\right)$ treatment compared to other treatments. Similar results were observed by Kumawat et $a l$. , (2006) The manganese content of grain in control was $7.28 \mathrm{mg} \mathrm{kg}^{-1}$ which increased significantly to $13.18 \mathrm{mg} \mathrm{kg}{ }^{-1}$ due to application of RDF + foliar spray of MM at 45 DAS. Similarly, highest concentration of manganese in stover was noticed in $\mathrm{T}_{6}(90.84$ $\mathrm{mg} \mathrm{kg}^{-1}$ ) due to application of RDF + foliar spray of micronutrients mixture at 30 and 45 DAS followed by $\mathrm{T}_{8}\left(86.67 \mathrm{mg} \mathrm{kg}^{-1}\right)$ and on par with $\mathrm{T}_{5}$. Similar reports were observed by Parker et al., (1981)

The zinc content in grain varied from 19.49 to $32.31 \mathrm{mg} \mathrm{kg}^{-1}$ in control and RDF + foliar spray of MM at 30 and 45 DAS, respectively and it was significantly higher compared to all other treatments. The zinc concentration in stover varied significantly due to application of micronutrients mixture. Similar reports were observed by Tripathi et al., (1997) Copper content of grain in control plot was $11.34 \mathrm{mg} \mathrm{kg}^{-1}$ which increased significantly to $14.78 \mathrm{mg} \mathrm{kg}^{-1}$ due to application of RDF + foliar spray of $\mathrm{MM}$ at 30 and 45 DAS. Application of $\mathrm{RDF}+$ foliar spray of micronutrients mixture at 30 and 45 DAS $\left(T_{6}\right)$ significantly increased the copper content (15.57 $\mathrm{mg} \mathrm{kg}^{-1}$ ) in grain compared to all other treatments except $\mathrm{T}_{5}$. The boron content in mungbean grain in control was significantly lower than that recorded in $\mathrm{T}_{6}\left(57.64 \mathrm{mg} \mathrm{kg}^{-1}\right)$ and $\mathrm{T}_{4}\left(55.29 \mathrm{mg} \mathrm{kg}^{-1}\right)$. While in stover, the $\mathrm{B}$ content recorded in $\mathrm{T}_{6}, \mathrm{~T}_{5}, \mathrm{~T}_{9}$ and $\mathrm{T}_{10}$ 
treatments were statistically at par with each other but differed significantly with other treatments. Similar increase in B content were observed by Oplinger et al., (1993). Among the treatments receiving micronutrients mixture at 30 DAS $\left(\mathrm{T}_{4}\right)$ and $45 \mathrm{DAS}\left(\mathrm{T}_{5}\right)$ micronutrient content in grains recorded highest in @ 30DAS. Results revealed that application of RDF +foliar application of MM at 30 and 45 DAS recorded significantly higher nutrient content of $\mathrm{Fe}, \mathrm{Mn}, \mathrm{Zn}, \mathrm{Cu}$ and $\mathrm{B}$ in mungbean grains, which was $77.44,80.9$, 65.77, 30.68 and 65.39 per cent, respectively higher over control and 43.99, 66.2, 17.90, 21.16 and 20.94 per cent, respectively higher over soil application of MM. It may be attributed to these micronutrients are required in the early stage of the crop for crop growth and metabolism activities. The improvement in the nutrients use efficiency could be attributed to an enhancement in absorption and assimilation of the micronutrients which provided balanced nutrition to the crop for higher growth and thereby nutrients content which ultimately resulted into higher yield of the crop.
When nutrients are taken up by the plant, the localization within the plant depends on multiple metabolic interactions that differ among plant species and varieties. The responses also firstly depend on specific plantmicronutrient interactions and on the nutrients, as interactions between nutrients that are combined can have positive as well as neutral or even negative effects on yields and nutrient use efficiencies (Rietra et al., 2015). Furthermore, nutrients are distributed over different plant organs and can be re-localized when plants require higher concentrations during certain development stages, such as increased transport to grains as they fill. Whether the micronutrients are actually (re-) located in the part of the plant which is consumed depends on the crop (variety). In rice for example, $\mathrm{Zn}$ is localized in protein bodies in the outer layer of the grains (Duffner et al., 2014). Other crops like wheat allocate $\mathrm{Zn}$ in the consumed part of the grain (endosperm) (Ajiboye et al., 2015) (Fig. 2).

Fig.1 Effect of micronutrient mixture application on grain and stover yield of mungbean

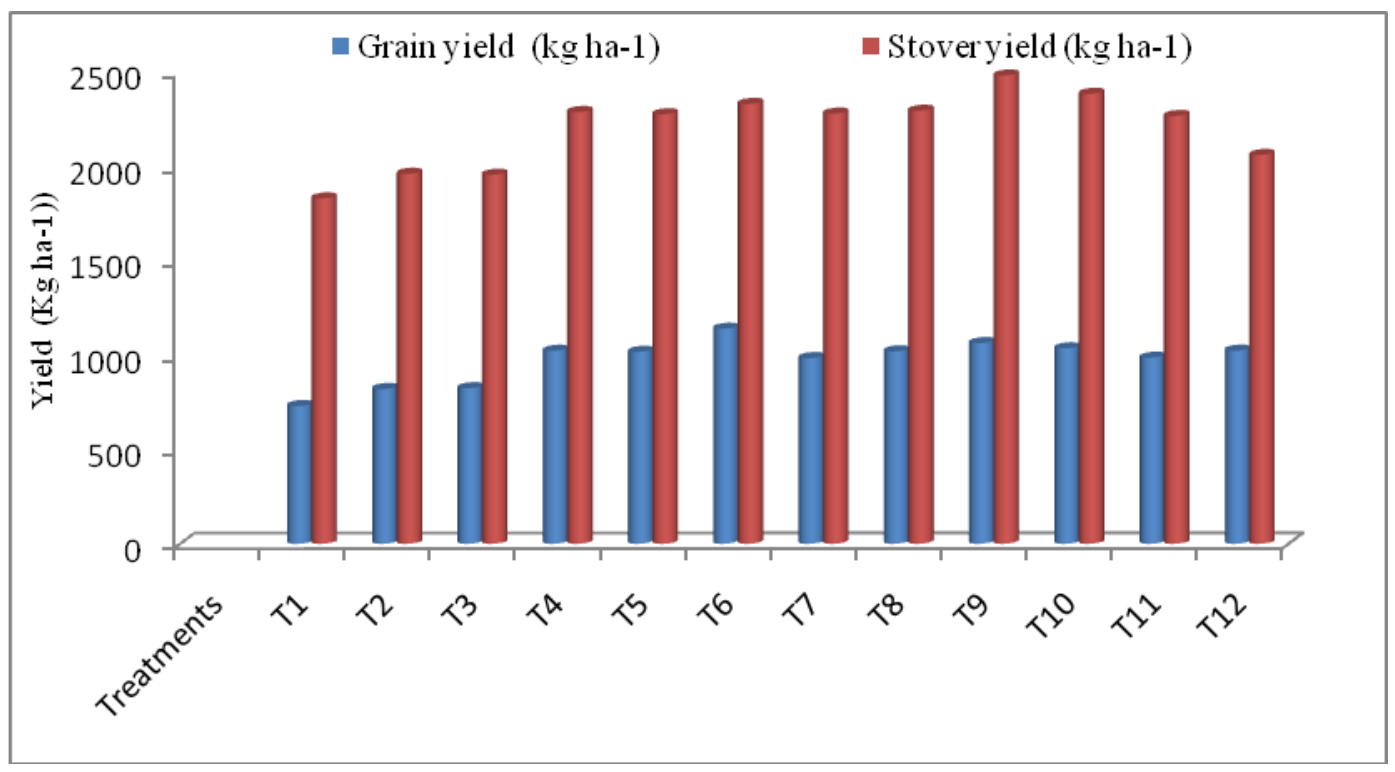


Fig.2 Micronutrient content in grain as influenced by application of micronutrients mixture

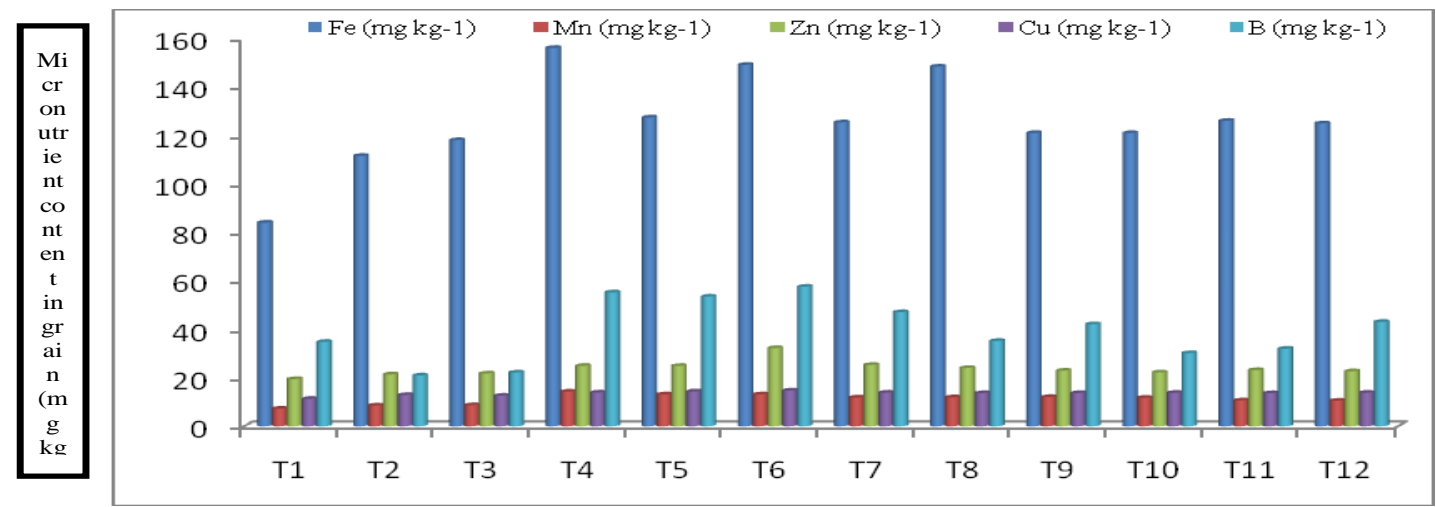

Treatments

Table.1 Micronutrient carrier and quantity used for soil and foliar application and seed treatment

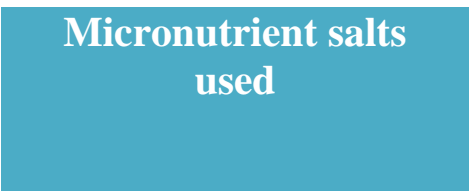

\begin{tabular}{|c|c|}
\hline Micronutrient \\
$\begin{array}{c}\text { percent in a mixture } \\
\text { for soil application }\end{array}$ & $\begin{array}{c}\text { Micronutrient for } \\
\text { foliar application }\end{array}$ \\
$(\mathrm{g} / \mathrm{ha})$
\end{tabular}

Micronutrient

percent in mixture

for seed treatment

\begin{tabular}{|l|}
\hline $\mathrm{Fe}_{2} \mathrm{SO}_{4} .7 \mathrm{H}_{2} \mathrm{O}$ \\
\hline $\mathrm{MnSO}_{4} .5 \mathrm{H}_{2} \mathrm{O}$ \\
\hline $\mathrm{ZnSO}_{4} \cdot 7 \mathrm{H}_{2} \mathrm{O}$ \\
\hline $\mathrm{CuSO}_{4} \cdot 7 \mathrm{H}_{2} \mathrm{O}$ \\
\hline Borax/solubur \\
\hline Ammonium molybdate \\
\hline
\end{tabular}

\begin{tabular}{|c|c|c|}
\hline 0.80 & 80.32 & 0.4 \\
\hline 0.97 & 65.08 & 0.3 \\
\hline 2.26 & 67.85 & 0.2 \\
\hline 0.50 & 25.43 & 0.1 \\
\hline 0.34 & 8.73 & 0.05 \\
\hline- & - & 0.01 \\
\hline
\end{tabular}

Table.2 Iron, manganese, zinc, copper and boron $\left(\mathrm{mg} \mathrm{kg}^{-1}\right)$ contents in mungbean grain and stover as influenced by application of micronutrients mixture

\begin{tabular}{|c|c|c|c|c|c|c|c|c|c|c|}
\hline \multirow[t]{2}{*}{ Treatments } & \multicolumn{2}{|c|}{$\mathbf{F e}\left(\mathrm{mg} \mathrm{kg}^{-1}\right)$} & \multicolumn{2}{|c|}{$\operatorname{Mn}\left(m g \mathrm{~kg}^{-1}\right)$} & \multicolumn{2}{|c|}{$\mathbf{Z n}\left(\mathrm{mg} \mathrm{kg}^{-1}\right)$} & \multicolumn{2}{|c|}{$\mathrm{Cu}\left(\mathrm{mg} \mathrm{kg}{ }^{-1}\right)$} & \multicolumn{2}{|c|}{$\mathbf{B}\left(\mathrm{mg} \mathrm{kg}^{-1}\right)$} \\
\hline & Grain & Stover & Grain & Stover & Grain & Stover & Grain & Stover & Grain & Stover \\
\hline$T_{1}$ & 84.10 & 341.82 & 7.28 & 54.63 & 19.49 & 32.59 & 11.34 & 7.04 & 34.85 & 36.89 \\
\hline$T_{2}$ & 111.64 & 413.99 & 8.60 & 57.61 & 21.43 & 35.78 & 12.92 & 9.31 & 20.99 & 46.45 \\
\hline $\mathbf{T}_{3}$ & 118.19 & 421.69 & 8.73 & 64.75 & 21.80 & 36.94 & 12.65 & 10.67 & 22.22 & 47.73 \\
\hline $\mathbf{T}_{4}$ & 156.22 & 696.90 & 14.32 & 82.33 & 24.97 & 42.98 & 13.95 & 12.43 & 55.29 & 52.42 \\
\hline$T_{5}$ & 127.51 & 565.48 & 13.18 & 84.97 & 24.92 & 45.83 & 14.41 & 13.88 & 53.55 & 64.32 \\
\hline$T_{6}$ & 149.23 & 720.39 & 13.17 & 90.84 & 32.31 & 48.94 & 14.78 & 15.57 & 57.64 & 66.63 \\
\hline $\mathbf{T}_{7}$ & 125.49 & 517.51 & 11.90 & 73.10 & 25.34 & 37.27 & 13.90 & 12.73 & 47.13 & 56.61 \\
\hline$T_{8}$ & 148.51 & 571.52 & 11.99 & 86.67 & 24.09 & 43.77 & 13.70 & 13.18 & 35.24 & 50.86 \\
\hline$T_{9}$ & 121.10 & 483.52 & 12.10 & 73.95 & 22.98 & 44.65 & 13.74 & 12.17 & 42.15 & 63.94 \\
\hline$T_{10}$ & 121.07 & 427.35 & 11.79 & 75.62 & 22.26 & 37.88 & 13.83 & 11.50 & 30.21 & 62.46 \\
\hline$T_{11}$ & 126.12 & 424.54 & 10.69 & 83.00 & 23.20 & 34.88 & 13.66 & 12.48 & 32.05 & 60.32 \\
\hline $\mathrm{T}_{12}$ & 125.07 & 428.21 & 10.56 & 78.38 & 22.73 & 38.56 & 13.87 & 12.13 & 43.11 & 54.52 \\
\hline SEm \pm & 8.93 & 32.68 & 0.44 & 2.36 & 1.20 & 1.17 & 0.46 & 0.64 & 1.20 & 1.62 \\
\hline $\mathrm{CD}(\mathrm{p}=0.05)$ & 26.53 & 97.07 & 1.32 & 7.01 & 3.57 & 3.48 & 1.38 & 1.89 & 3.57 & 4.81 \\
\hline
\end{tabular}


Table. 3 Correlation matrix between grain nutrient content $\left(\mathrm{mg} \mathrm{kg}^{-1}\right)$ and yield $\left(\mathrm{Kg} \mathrm{ha}^{-1}\right)$

\begin{tabular}{|c|l|l|l|l|l|c|}
\hline Parameter & \multicolumn{1}{|c|}{ Yield } & \multicolumn{1}{|c|}{ Fe } & \multicolumn{1}{|c|}{ Mn } & Zn & Cu & B \\
\hline Yield & 1 & & & & & \\
\hline Fe & $0.77^{*}$ & 1 & & & & \\
\hline $\mathbf{M n}$ & $0.88^{* *}$ & $0.85^{* *}$ & 1 & & & \\
\hline $\mathbf{Z n}$ & $0.74^{*}$ & $0.72^{*}$ & $0.70^{*}$ & 1 & & \\
\hline $\mathbf{C u}$ & $0.94^{*}$ & $0.80^{*}$ & $0.88^{*}$ & $0.78^{*}$ & 1 & \\
\hline B & $0.66^{*}$ & 0.56 & $0.78^{*}$ & $0.72^{*}$ & $0.64 *$ & 1 \\
\hline
\end{tabular}

*Significant at $5 \%$ level. **Significant at $1 \%$ level

Table.4 DTPA extractable iron, manganese, zinc, copper and hot water soluble boron ( $\mathrm{mg} \mathrm{kg}^{-1}$ ) content of soil as influenced by application of micronutrients mixture

\begin{tabular}{|c|c|c|c|c|c|}
\hline Treatments & $\mathrm{Fe}\left(\mathrm{mg} \mathrm{kg}^{-1}\right)$ & $\operatorname{Mn}\left(m g \mathrm{~kg}^{-1}\right)$ & $\mathrm{Zn}\left(\mathrm{mg} \mathrm{kg} \mathrm{g}^{-1}\right)$ & $\mathrm{Cu}\left(\mathrm{mg} \mathrm{kg}^{-1}\right)$ & B $\left(\mathrm{mg} \mathrm{kg}^{-1}\right)$ \\
\hline $\mathrm{T}_{1}$ & 7.21 & 8.17 & 0.43 & 0.38 & 0.41 \\
\hline $\mathbf{T}_{2}$ & 7.44 & 8.21 & 0.66 & 0.43 & 0.42 \\
\hline $\mathbf{T}_{3}$ & 7.77 & 8.28 & 0.63 & 0.44 & 0.42 \\
\hline $\mathbf{T}_{4}$ & 7.48 & 8.22 & 0.87 & 0.47 & 0.47 \\
\hline $\mathbf{T}_{5}$ & 7.66 & 8.43 & 0.86 & 0.43 & 0.41 \\
\hline$T_{6}$ & 7.85 & 8.39 & 0.86 & 0.45 & 0.59 \\
\hline $\mathbf{T}_{7}$ & 7.61 & 8.31 & 0.85 & 0.47 & 0.49 \\
\hline $\mathrm{T}_{8}$ & 7.76 & 8.63 & 0.89 & 0.40 & 0.49 \\
\hline$T_{9}$ & 9.50 & 8.88 & 1.10 & 0.51 & 0.77 \\
\hline $\mathbf{T}_{10}$ & 8.11 & 8.74 & 0.93 & 0.49 & 0.61 \\
\hline $\mathbf{T}_{11}$ & 7.95 & 8.43 & 0.91 & 0.47 & 0.65 \\
\hline $\mathbf{T}_{12}$ & 7.47 & 8.37 & 0.81 & 0.41 & 0.42 \\
\hline SEm \pm & 0.34 & 0.39 & 0.03 & 0.03 & 0.03 \\
\hline $\mathrm{CD}(\mathrm{p}=0.05)$ & 1.00 & NS & 0.08 & NS & 0.09 \\
\hline
\end{tabular}

Correlation matrix of nutrient content in grain and yield indicated the importance of micronutrient mixture application (Table 3).

The grain nutrient content and crop yield were significantly and positively correlated. With increased micronutrient content in grain increased crop yield was observed.

The correlation between iron, manganese, zinc, copper and boron content in grain and crop yield was $+0.77,+088,+0.74,0.94$ and $+0.66$
Effect of micronutrients mixture on micronutrient availability in soil (DTPA extractable $\mathrm{Fe}, \mathrm{Mn}, \mathrm{Zn}, \mathrm{Cu}$ and Hot water soluble B)

The data on soil micronutrient status is represented in the Table 2. The DTPA extractable Fe content in soil at harvest was significantly higher in $\mathrm{T}_{9}\left(9.50 \mathrm{mg} \mathrm{kg}^{-1}\right)$ due to RDF + soil application of MM treatment than control $\left(7.21 \mathrm{mg} \mathrm{kg}^{-1}\right)$ and to all other treatments. Similar results were observed by Kumawat et al., (2006). The manganese 
content did not record significant variation due to different treatments. However, the highest available manganese content of soil was recorded in $\mathrm{T}_{9}\left(8.88 \mathrm{mg} \mathrm{kg}^{-1}\right)$ due to $\mathrm{RDF}$ + soil application of $\mathrm{MM}$ treatment than control $\left(8.17 \mathrm{mg} \mathrm{kg}^{-1}\right)$.

The data clearly indicates that DTPA- Zn content significantly varied due to treatments. Significantly higher zinc content of soil was recorded in $\mathrm{T}_{9}\left(1.10 \mathrm{mg} \mathrm{kg}^{-1}\right)$ due to $\mathrm{RDF}+$ soil application of MM treatment than control $\left(0.43 \mathrm{mg} \mathrm{kg}^{-1}\right)$ and other treatments (Table 4). The effect of application of RDF and micronutrients mixture on available copper was non-significant at harvest. However, the highest copper concentration at harvest of crop was recorded in $\mathrm{T}_{9}\left(0.51 \mathrm{mg} \mathrm{kg}^{-1}\right)$ due to application of RDF + soil application of MM over control. The effect of application of RDF and micronutrients mixture on available boron was significant at harvest. The results revealed that the available boron ranging from 0.41 to $0.77 \mathrm{mg} \mathrm{kg}^{-1}$ due to treatments. The highest concentration of boron $0.77 \mathrm{mg} \mathrm{kg}^{-1}$ was recorded in $T_{9}$ treatment followed by $T_{11}$ (0.65 $\mathrm{mg} \mathrm{kg}^{-1}$ ) compared to control and other treatments. Application of micronutrients through fertilizer improves the soil fertility and productivity by increasing the nutrient availability in the soil and yield of the crop. Due to residual soil fertility the nutrients availability increased to the subsequent crop thereby increasing the yield similar reports were reported by Kannan et al., (2014).

Foliar or soil application of micronutrients mixture along with RDF significantly increased the yield and yield attributes, nutrient concentration in grain. The nutrient content in both grain and stover increased significantly with the application RDF + foliar application of micronutrients mixture followed by soil application of RDF + micronutrients mixture. Soil application of micronutrients mixture along with RDF significantly increased available macro and micronutrients there by increased the soil fertility level. Significantly higher available $\mathrm{N}, \mathrm{P}, \mathrm{K}, \mathrm{Ca}, \mathrm{Mg}, \mathrm{S}, \mathrm{Fe}, \mathrm{Mn}, \mathrm{Zn}, \mathrm{Cu}$ and $\mathrm{B}$ were noticed due to soil application of RDF + micronutrients mixture.

\section{References}

Ajiboye, B., Cakmak, I., Paterson, D., De Jonge, M.D., Howard, D.L., Stacey, S.P., Torun, A.A., Aydin, N. and Mclaughlin, M..J., 2015, X-ray fluorescence microscopy of zinc localization in wheat grains bio fortified through foliar zinc applications at different growth stages under field conditions. Plant Soil 392:357-370.

Duffner, A., Hoffland, E., Stomph, T.J., Melse-Boonstra, A. and Bindraban, P.S., 2014, Eliminating zinc deficiency in rice-based systems. VFRC Report 2014/2. Virtual Fertilizer Research Center, Washington, D.C

FAOSTAT, 2009, "Online Interactive Database on Agriculture", FAOSTAT. www.fao.org

Hazra, P., Maity, T.K. and Mandal, A.R., 1987, Effect of foliar application of micronutrientson growth and yield of okra (Abelmoschus esculentus L). Prog. Hort., 19: 219-222.

Hegde, D.M., Sudhakara Babu, S.N. and Murthy Iyln, 2007, Role of Customized Fertilizers in the Improvement of Productivity of Different Crops and Cropping Systems. In Proceedings of national seminar on "Standards and Technology of Value Added / Fortified / Customized Fertilizers as a Source of Plant Nutrients".(ICAR- IISS, Bhopal, India).

Hemn. O. S., 2013, Effect of Foliar Fertilization of Fe, B and $\mathrm{Zn}$ on nutrient concentration and seed protein of 
Cowpea "Vigna Unguiculata". J. Agri. Vet. Sci., (6): 42-46.

Iqtidar, A. and Rahman, S. F., 1984, Effect of boron on the protein and amino acid composition of wheat grain. J Agric. Sci., UK, 103(1): 75-80.

Kannan, P., Arunachalam, P., Prabukumar, G., and Prabhaharan, J., 2014, Response of Blackgram (Vigna mungo L.) to multi micronutrients mixtures under Rainfed Alfisol. J. Indian Soc. Soil Sci., 62(2): 154-160.

Kumawat, R.N., Rathore, P.S. and Pareek, N., 2006, Response of mungbean to sulphur and iron nutrition grown on calcareous soil of Western Rajasthan.Indian $J$. Pulse Res., 19: 228-230.

Lindsay, W.L. and Norvell, W.A., 1978, Development of DTPA soil test for zinc on, manganese and copper. Soil Sci. Soc. American J., 42: 421-428.

Oplinger, E.S., Hoeft, R.G., Johnson, J.W. and Tracy, P.W., 1993, Boron fertilization of soybeans: A regional summary. p. 7-16.

Page, A.L., Miller, R.H. and Keeney, D.R., 1982, Methods of Soil Analysis. Part 2Chemical and Microbiological Properties. 2nd Edition. Agronomy No. 9 Part 2.ASA, SSSA, Madison, Wisconsin, USA.

Parker, M.B., Boswell, F.C., Ohli, K., Shuman, L.M. and Wilson, D.O., 1981, Manganese effects on yield and nutrient concentration in leaves and seed of soybean cultivars. Agron. J.73: 643646.
Poongothai, S. and Chitdeshwari, T., 2003, Response of blackgram to multi micronutrients mixture. Madras Agric. J., 90(7-9): 442-443.

Quddus, M.A., Rashid, M.H., Hossain, M.A., and Naser, H.M., 2011, Effect of zinc and boron on yield and yield contributing characters of mungbean in low Ganges river floodplain soil at Madaripur. Bangladesh. Bangladesh J. Agril. Res., 36(1): 75-85

Raj, S., 1985, An Introduction to physiology of field crops, Oxford and IBH Publishing Co.. New Delhi. pp. 94-97.

Rietra, R.P.J.J., Heinen, M., Dimpka, C. and Bindraban, P.S., 2015, Effects of nutrient antagonism and synergism on fertilizer use efficiency. Virtual Fertilizer Research Centre, Washington, DC.

Savithri, P., 2001. In: National Symposium on Pulses and Oilseeds for Sustainable Agriculture. 29-31, July, 2001. Tamil Nadu Agric. Univ. Coimbatore, pp.87.

Tripathi, H.C., Singh, R.S. and Mishra, V.K., 1997, Effect of $\mathrm{S}$ and $\mathrm{Zn}$ nutrition on Yield and quality of chick pea (Cicer arietinum L.). J. Indian Soc. Soil Sci., 45:123-126

Valenciano, J. B., Boto, J.A. and Marcelo, V., 2010, Response of chickpea (Cicer arietinum L.) Yield to zinc, boron and molybdenum application under pot conditions. Spanish J. Agril. Res., 8(3):797-807.

\section{How to cite this article:}

Divyashree, K.S., S.S. Prakash, S.B. Yogananda and Chandrappa. 2018. Seed Yield and Nutrient Content of Mungbean and Soil Nutrient Status as Influenced by Application of Micronutrients Mixture in a Alfisol. Int.J.Curr.Microbiol.App.Sci. 7(09): 1706-1713. doi: https://doi.org/10.20546/ijcmas.2018.709.206 